\title{
The Validity of Molecular Geometry Based Virtual Reality to Improve Student Visual-Spatial Intelligence in New Normal Era
}

Ainun Nisa*, Ikfisani Yuniar Rifki, Aiza Alya, Kusumawati Dwiningsih

Chemistry Education, FMIPA, University State of Surabaya, Surabaya, 60321, Indonesia

\section{ARTICLE INFO}

Article history:

Received: 08 Dec 2020

Revised: 24 April 2021

Accepted: 13 June 2021

Published online: 24 July 2021

\section{Keywords:}

Reality

The Validity

Molecular Shape Geometry

New Normal Era

\begin{abstract}
A B S T R A C T
The Ministry of Education and Culture of the Republic of Indonesia issued policies related to the implementation of education in the new normal era learning systems through online learning by utilizing various technologies. Without face-to-face learning, high school students have difficulty in understanding molecular shape geometry material so that it affects students' ability to develop spatial-visual precepts. As a solution to these problems, there needs to be the development of virtual reality learning videos that match the geometry of molecular shapes in real-time. This study aims to find out the validity of The Virtual Reality-Based Molecular Shape Geometry Tutorial Video As a Solution To Improve the Spatial Visual Ability of High School Students in the New Normal Era. Validity is tested through content quality and purpose, instructional quality, and technical quality. The development was carried out using the R\&D method with The Thiagarajan 4D model (Define, Design, Develop, and Disseminate which is limited to the Develop Stage The results were obtained from Virtual Reality Chemistry (VR CHEM) media are very valid on each criterion assessed. The details of the results obtained are content validation of $91.9 \%$ and construction validation of $89 \%$.
\end{abstract}

\section{Introduction}

The Covid-19 pandemic is a devastating disaster for the entire population of the earth. All segments of human life on earth are disrupted, without exception education. Many countries decided to close schools, colleges, and universities, including Indonesia (Aji, 2020). Since entering the new normal era due to the Covid-19 pandemic all activities must run following health protocols. The learning process in the world of education must also implement to reduce the spread of the Covid-19 virus. The social distancing and work from home policies that are currently still being applied make the learning process that initially

\footnotetext{
${ }^{*}$ Corresponding author. 
gathers in one class to be considered because it has the potential to trigger congregation. Therefore, to overcome this the learning of online subvert. According to firman, online learning can be implemented synchronous and asynchronous. Learning through video conferencing such as the Zoom app and Google Meet makes lecturers and students able to meet and communicate. This learning is called synchronously. While learning using Google Classroom, Emodo, Whatsapp, and email apps are learning asynchronously. Lecturers can upload content such as reading materials, videos, or material links (Firman, 2020).

Wasis (2013) states that 21st-century education not only pays attention to core subjects as it did in the previous century, but also emphasizes life skills, learning and thinking skills, and literacy in information and communication technology (ICT literacy). The development of the 21 st Century learning process creates new innovations in education, especially in the innovation of learning media. One of the functions of learning media is to overcome the limitations of space, time, and sensory power (Sadiman, 2014). This function to address the subject of events or events that occurred in the past bias is displayed again through video recording, objects that are too large biased are replaced with images, and so on. Besides, learning media should also be able to capture goals and teaching materials more easily and faster so that students can easily understand them.

Chemistry is one of the clumps of Natural Sciences (IPA). Chemistry is a science that studies facts, concepts, and principles of chemistry (Sukmawati, 2019). Chemistry is one of the lessons that must be learned by high school students, especially high school students who choose science programs. According to Supriono (2018), chemistry subjects are difficult subjects because they are abstract and complex, requiring high levels of reasoning and thinking that cause learning difficulties in students. According to Puspendik (2019), the average score data of chemical subjects on computer-based national exams in Indonesia still reaches 50.99. The data proves that chemistry subjects are difficult subjects.

The molecular form is one of the materials in chemistry that is abstract and requires good space visibility so to understand it requires high abstraction power because the molecular form learns about the three-dimensional arrangement of atoms in a molecule (Setiawan, 2017). This is evidenced by the results of preresearch questionnaire responses $78 \%$ of wachid hasyim 2 taman high school students argue that submits matter forms molecules are elusive. These learning difficulties can be overcome by the building of a learning medium. Some chemicals require learning media as a model following KD 4.6 Permendikbud No 37, 2018 on the molecular shape geometry sub material of high school chemistry lesson class X.

The sub-material geometry of molecular shapes is actually easy to understand if the concept of the bond is realized, using learning media in the form of learning videos so that the concept of bonding is more real than just the concept written in the book of teaching and molymod whose angles sometimes do not match. According to Sherin (2017), learning videos aimed at helping communicate the messages delivered can further give the recipient the message "Video today is 
often used for demonstration and evaluation, but we believe that a more productive approach is to use video to support teachers' ability to notice and interpret classroom interactions".

Video is a moving image that can show the actual situation, circumstances, or shape, the video can only display images in 2 dimensions. The user cannot feel the same condition. This becomes the weak point of a learning video, so the learning video is still not able to convey the message or material to the maximum. The use of learning videos is an effective strategy, as it can provide examples of modeling on how to perform a task (Hoogerheide, 2016). Weaknesses in regular learning videos provide an idea to develop with Virtual Reality. Virtual reality is one of the technologies used in the XXI Century, where it is expected to master global development.

Virtual Reality (VR) is one of the few technologies receiving attention for its potential use in education, with the European Union and the US launching initiatives for large-scale implementation of digital technology in the classroom (American Library Association, 2017). VR has been developed in several developed countries such as the United States, this can be a reference to why Indonesia does not utilize technology such as in the continent and Europe.

According to Abdillah (2018), Virtual Reality or what in Bahasa Indonesia is called virtual reality is a technology simulated by a computer or smartphone that can make users interact in an environment in real-time or its term a computersimulated environment, meaning that the computer simulates a virtual environment and is projected on virtual reality media that makes it seem as if the user is entering into that world or environment. The arrival of VR can help with learning difficulties in abstract sub-material molecular shapes and it takes tools to project an image of a chemical bond in a molecule. This has been proven in VR cell biology material has the potential as an educational technology that improves objective learning results and learning motivation of students (Meyer, 2019). Many materials in science study things that are abstract and may not be able to be seen in real life, such as home design, the solar system, and medicine. With VR it can be done because VR displays a virtual object to be real. The ability to see or imagine something abstract relates to the intelligence that each individual has in visualizing virtual objects, this intelligence is called spatial-visual intelligence.

Visual-spatial intelligence combines a person's ability to visualize by altering imaginary power or manipulation of objects in space (Ahvan and Hossein, 2016). This intelligence is necessary to predict the results of an object manipulation so that it is expected that the desired goal is achieved, such as in the sub-material of the molecular shape, in the hope that the learner can predict if a molecular shape geometry is projected to change. Spatial Visual Ability is the ability to understand or recognize the position of a shape or object (Critten, 2018). In understanding the molecular form material of students is expected to have a minimum level of visual-spatial intelligence above average. According to Stiani (2018), visualspatial intelligence is said to be high if the visual-spatial test score is more than 70. The visual-spatial intelligence tests that have been conducted obtained an 
average test score of 32.57 , the value is still relatively low, so it needs to be improved so that students can predict a virtual object to be read correctly. The development of VR technology can help students improve visual-spatial intelligence because in VR there are two important things in its development: spatial and visual prestige (Gerschütz, 2019).

Based on the description above this research aims to improve the spatial visual intelligence of students and motivate students to be more passionate about learning and utilizing technology following the global development of unraveling in the COVID-19 pandemic era. Molecular shape material, especially in the geometry of molecular shapes that were initially considered difficult by the development of virtual reality-based learning videos will be easier because can show the geometry of more real molecular shapes.

\section{Methodology}

\section{Research Design}

This development research uses 4D Thiagarajan (Define), Design (design), Develop (development), and Disseminate models that are limited to the Develop stage. Product development in this research is in the form of learning media. The media developed will be assessed by media experts and two chemistry teachers. So it is expected that this learning media can be used in the process of chemical learning in the sub-material Geometry of Molecular Shapes (Ibrahim, 2001).

\section{Define Stage}

At this stage, competency analysis is carried out covering the Standard competency of graduates (SKL), core competencies (KI), and basic competencies (KD) following the limitations of competencies and related materials in the media that are being developed. The purpose of this stage is to define and define the terms of learning. This stage consists of 5 parts that need to be done, namely curriculum analysis, student analysis, task analysis, concept analysis, and the formulation of learning objectives.

\section{Design Stage}

At this stage, a draft of VR-based learning video building components is carried out. This aims to design a media format that will be developed and the description of the material that will be discussed in a learning media. This stage is divided into two parts, namely the design and manufacturing stages. At the design stage, the drafting of VR-based learning video components of molecular shape geometry includes media display formats such as 2-dimensional, and 3-dimensional, animation, and audio images. At the decay stage, the process of creating VRbased learning videos begins with creating supporting equipment, such as layout design, content content, and molecular shapes in 3 dimensions and real. This VR- 
based learning video development uses Unity's main software and several other supporting software including Adobe Illustrator CC 2017, and Blender 3D.

\section{Development Stage}

At this stage, it includes; study and validation of the device by experts, namely one media expert lecturer and two chemistry teachers followed by revisions. This stage aims to produce a revised learning device based on inputs and suggestions by experts the results obtained will be used as the basis for revision.

\section{Product Assesment and Analysis Stage}

The data obtained is analyzed using data analysis techniques and feasibility of data analysis. Data from the study in the form of suggestions and inputs from the study consisting of expert media lecturers are used to improve the learning videos that have been developed. The study analysis will be done by a qualitative descriptive analysis method. The data of media feasibility results will be assessed by media experts and material experts, namely one lecturer and two high school chemistry teachers using media validation instruments. Ratings are given on a Likert scale of 1-5 in table 1 (Riduwan, 2007).

Table 1. Likert Scale

\begin{tabular}{cc}
\hline Criteria & Score \\
\hline Not Good & 1 \\
Less Good & 2 \\
Enough & 3 \\
Good & 4 \\
Excellent & 5 \\
\hline
\end{tabular}

Furthermore, the data of the assessment results of experts are analyzed descriptively quantitatively. The research data was analyzed with the formula:

$$
\mathrm{P}(\%)=\left(\sum \text { obtained }\right) /(\text { cryptic score }) \times 100 \%
$$

Cryptium score $=$ highest score of each item $\times$ number of items $\times$ number of validators.

Furthermore, the percentage score obtained will be interpreted to find out the feasibility value of VR-based learning videos of molecular shape geometry. The score interpretation table that shows the large percentage of validation assessments against VR-based learning videos of molecular shape geometry by validators is in table 2 (Riduwan, 2007).

Table 2. Interpretaion of The Validity of Each Criterion

\begin{tabular}{cc}
\hline Percentage (\%) & Assessment \\
\hline $0-20$ & Very Less \\
$21-41$ & Less \\
$41-60$ & Enough \\
$61-80$ & Valid \\
$81-100$ & Very Valid \\
\hline
\end{tabular}


Based on table 2. VR learning media Chem is said to be Valid if it obtains a percentage of $61 \%$.

\section{Results and Discussion}

This research was conducted by R\&D method with the 4D model Thiagarajan (Define), Design (design), Develop (development), and Disseminate (deployment) which is limited to the Develop stage (Ibrahim, 2001). Product development in this research is in the form of learning media. The media developed will be assessed by one media expert lecturer and two chemistry teachers. So it is expected that this learning media can be used in the process of chemical learning in the sub-material Geometry of Molecular Shapes.

\section{Definition Stage}

At this definition, the stage can be analyzed that according to Permendikbud number 37 the year 2018 molecular shape geometry lies in KD 3.6 and 4.6 Applying the theory of valence skin electron pairs (VSEPR) and electron domain theory in determining molecular shape. Based on these basic competencies, it is known that the concepts that will be developed in this research are:

1) VSEPR Theory (Valence Shell Electron Pair Repulsion)

2) Hybridization Theory

Since entering the new normal era due to the Covid-19 pandemic all activities must run following health protocols. The learning process in the world of education must also apply this to reduce the spread of the Covid-19 virus. Social distancing and work from home policies that are currently still in place make the learning process that was originally gathered in one class a thing to consider because it has the potential to trigger confusion. Therefore, to overcome this, learning is pretexted online.

According to The Word, online learning can be carried out in synchronous and asynchronous ways. Learning through video conferencing such as the Zoom app and Google Meet makes lecturers and students able to meet and communicate. This learning is called synchronously. While learning using Google Classroom, Emodo, Whatsapp, and email applications are learning asynchronously. Lecturers can upload content such as reading materials, videos, or material links (Firman, 2020). So that the right learning media is needed to overcome the limitations of space and time, such as video learning. According to Sherin (2017), learning videos aim to help communicate the messages conveyed can give more understanding to the recipients of the message, but the learning video is used in the form of 2 Dimensions. It is lacking in the delivery of learning messages, especially on the geometric material of molecular shapes that have microscopic concept properties, so that in its delivery there need to be real illustrations. This can be overcome by the existence of Virtual Reality technology where this technology can make users feel present in the illustration environment. 
Reality is the appearance of a three-dimensional image created by a computer so that it looks real with the help of a certain amount of equipment, which makes its users seem to be physically involved in the environment (Bento de Sa, F., Carvalho de Paiva, R., Souki, G., \& Moura, 2017). Virtual Reality needs a device designed for a specific purpose in this technology, so it can make people who feel the virtual world be fooled and believe that what it is experiencing is real. Some of the devices used include Force balls/tracking balls, Controller wands, Voice recognition, Headsets, Joysticks/gamepads, Data gloves, Treadmills, Motion trackers/bodysuits. Based on the explanation above, it can be said that "Video Tutorial Geometry of Molecular Form-Based Virtual Reality (VR CHEM)" as a learning medium is needed to be developed so that learners' learning interests and spatial visual abilities can be improved.

With the goal that will be achieved after the implementation of VR-based learning videos, learners can define the geometry of molecular shapes, compare molecular shapes according to hybridization theory and VSEPR, explain the process of forecasting molecular shapes, and can improve spatial visual abilities.

\section{Design Stage}

At the media design stage, drafting the components of VR-based learning video geometry of molecular shapes that include media display formats such as title, creator, introduction (Preface, SK, KD, and Learning Objectives), 3-dimensional molecules, molecular shape geometry material, animation, problem making, answer key and audio as shown in figure 1 .

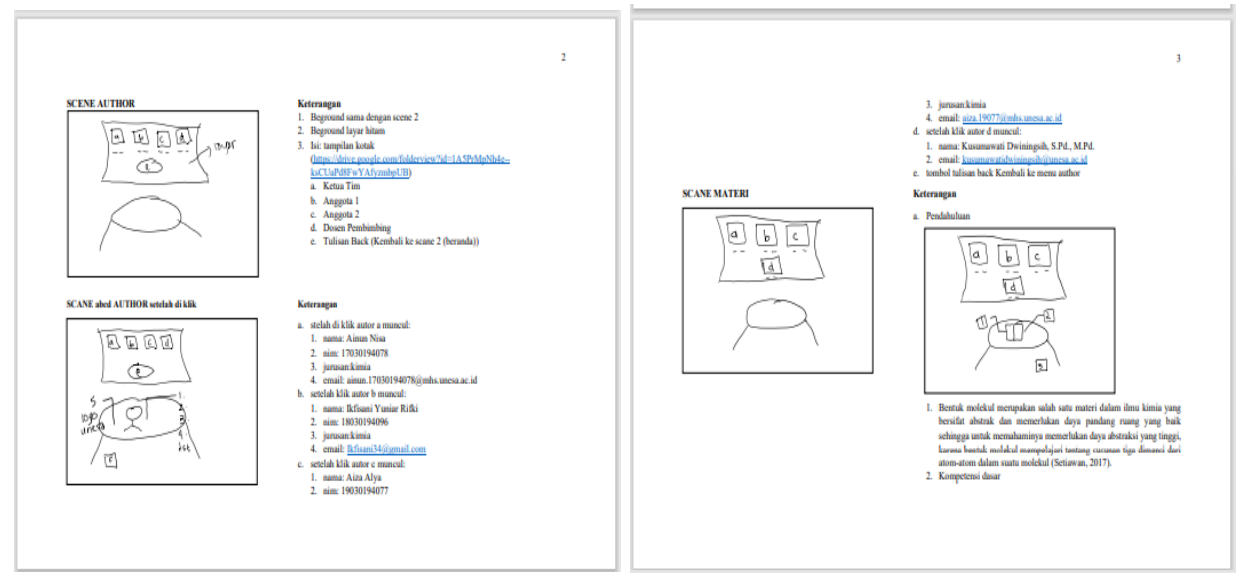

Figure 1. Early Media Storyboard

In the VR-based learning video development phase, the process of creating VRbased learning videos begins with creating supporting tools, such as layout design, content content, and molecular shapes in 3 dimensions and real. This VR-based learning video development uses Unity's main software and several other supporting software including Adobe Illustrator CC 2017, and Blender 3D. 


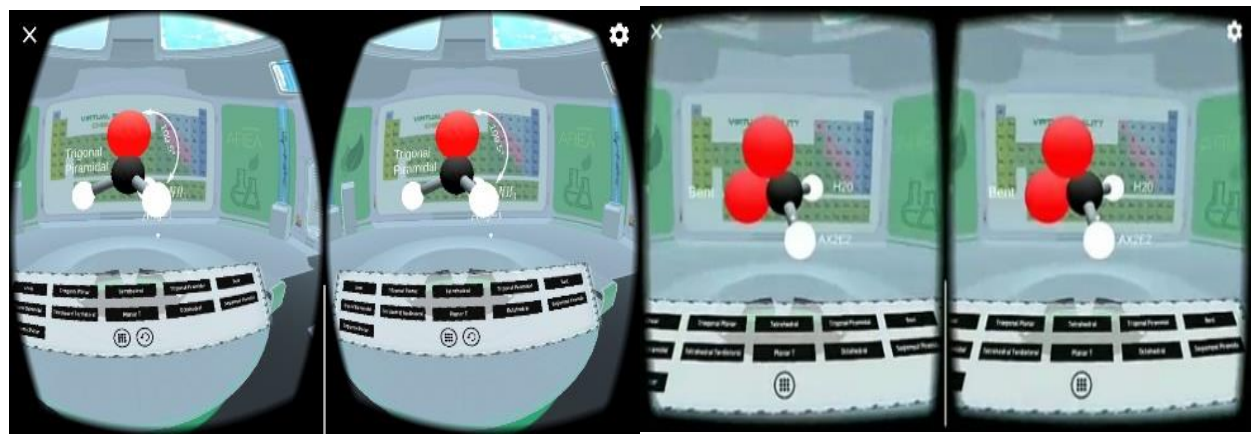

Figure 2. 3D Illustration of VSEPR theoretical molecular shape geometry

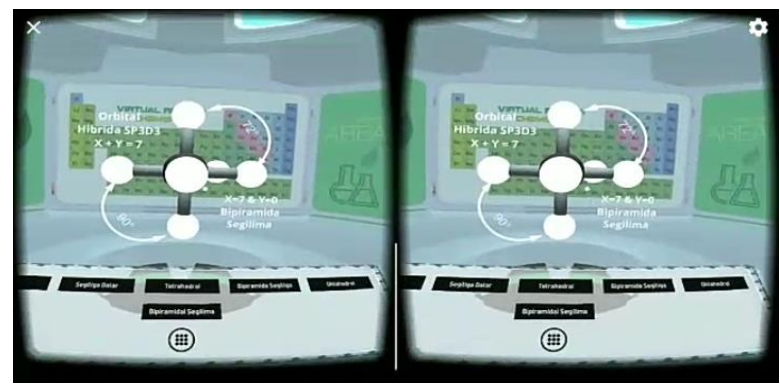

Figure 3. 3D Illustration of Molecular Shape Geometry Hybridization Theory

In the learning video, there are 11 3D illustrations of VSEPR theoretical molecular shape geometry and 6 3D illustrations of molecular shape geometry hybridization theory. Reference 3D illustration of molecules as shown in figure 4.
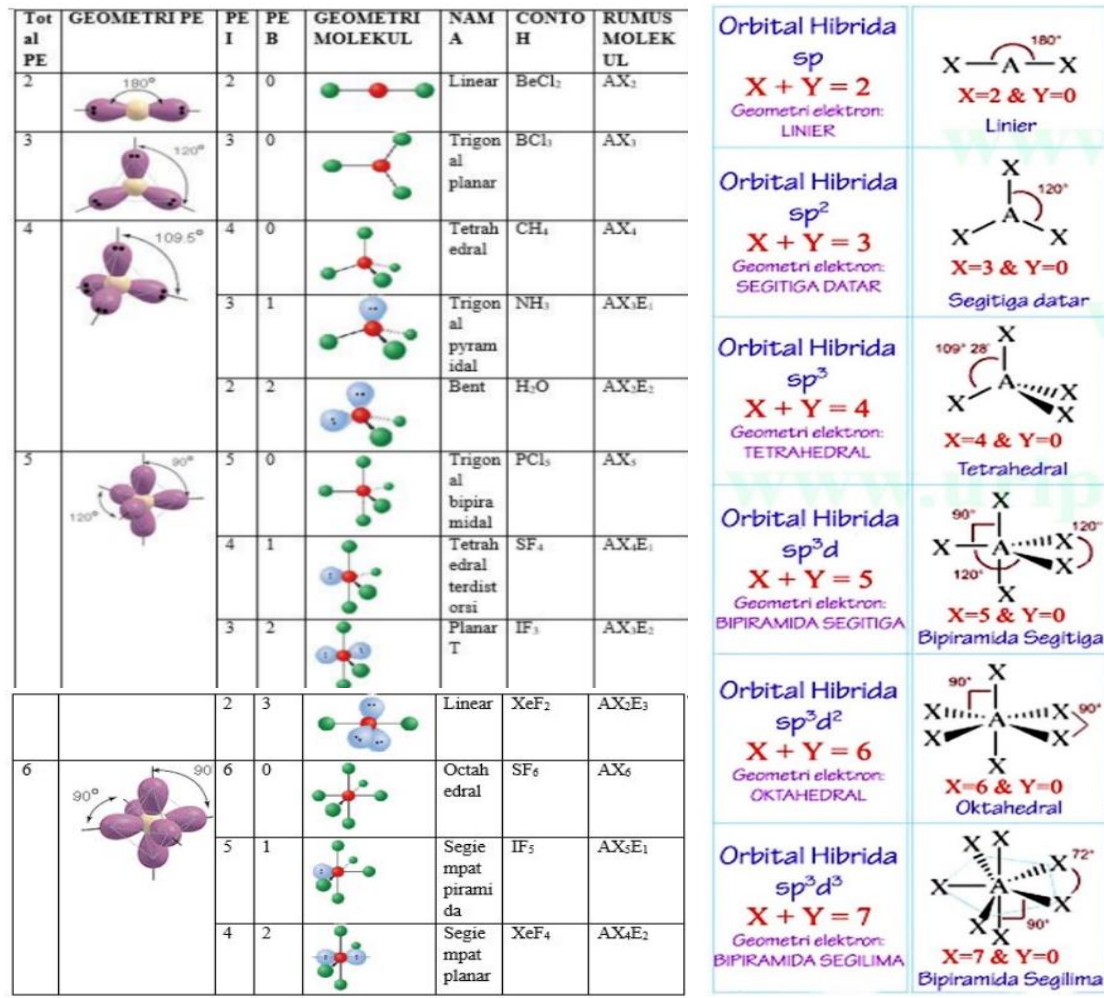

Figure 4. VSEPR Theory and Hybrid Theory 
In the CHEM VR Learning Video, there are also practice questions that train the spatial visual abilities of learners, there are 10 questions equipped with recap points obtained after answering the question exercises such as figure 5 .

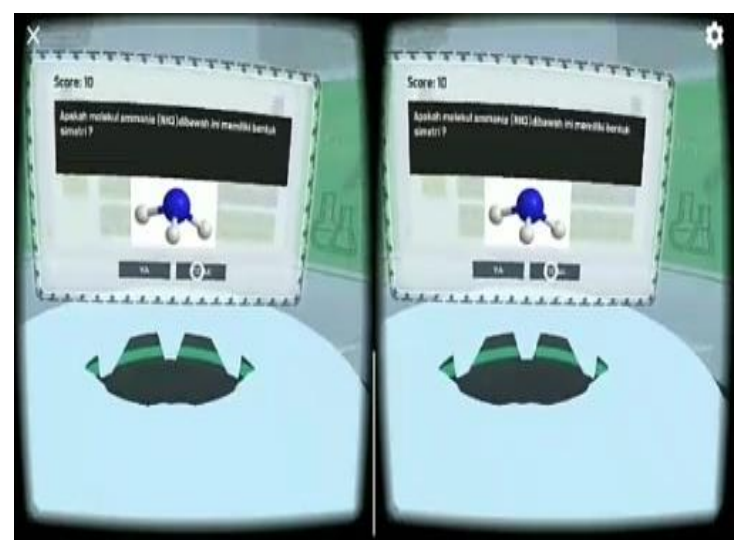

Figure 5. Exercise Problem VR Chem

\section{Development Stage}

At this stage, it includes; (a) Study (b) Validation of the device by one media expert lecturer and two chemistry teachers followed by revision. This stage aims to produce a revised learning device based on inputs and suggestions by experts, the results obtained will be used as the basis for revision.

After planning the learning media, VR-based learning videos of the molecular form will be created and produce the initial draft/storyboard of the VR CHEM application as stated in table 3 .

Table 3. VR Chem Initial Draft View

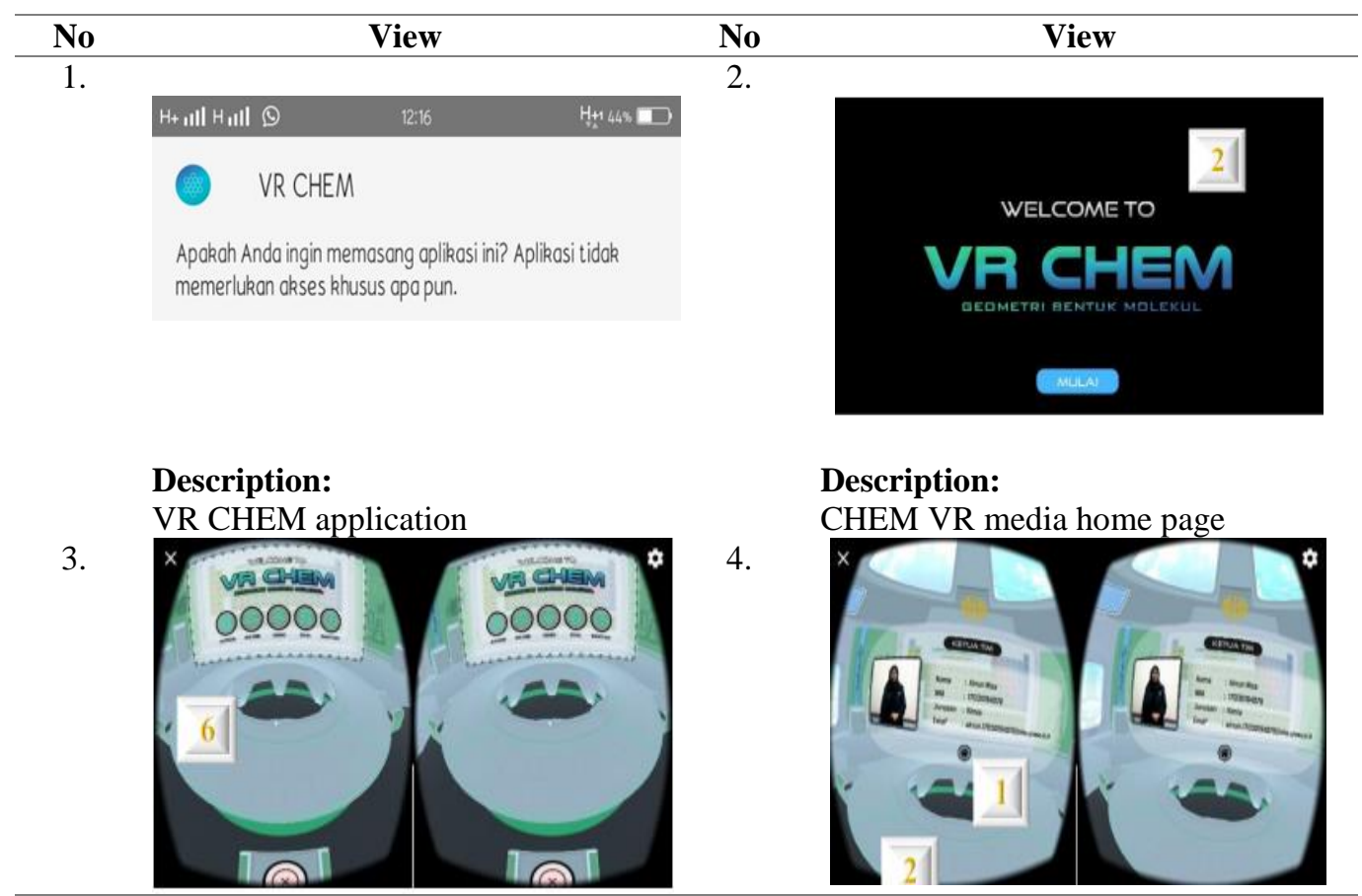




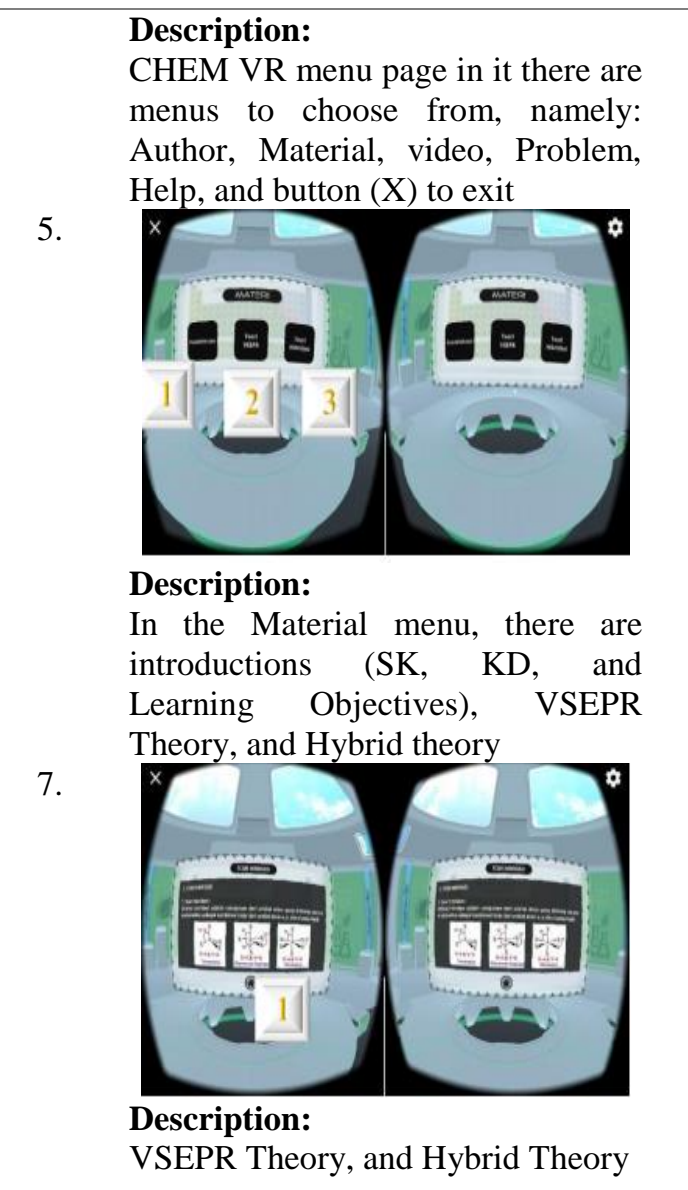

9.

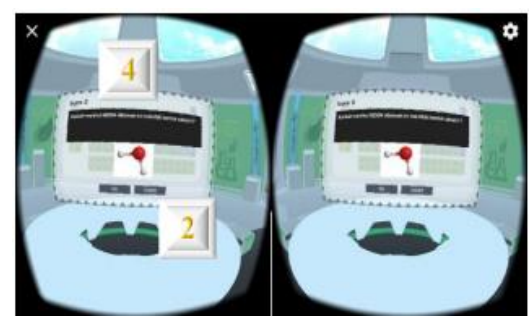

Description:

In the Problem menu, there is a problem of molecular geometry that trains the spatial visual abilities of learners

\section{Description:}

On the Author menu, there is media maker data

6.

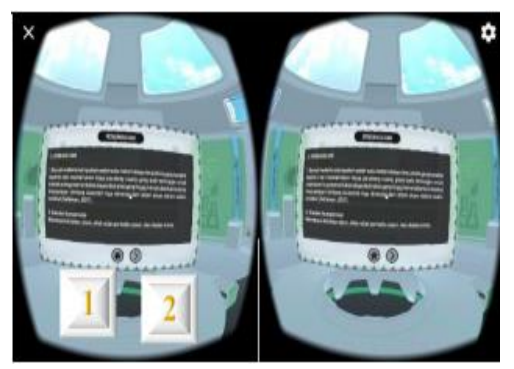

Description:

On the Introduction menu (SK, KD, and Learning Objectives)

8.

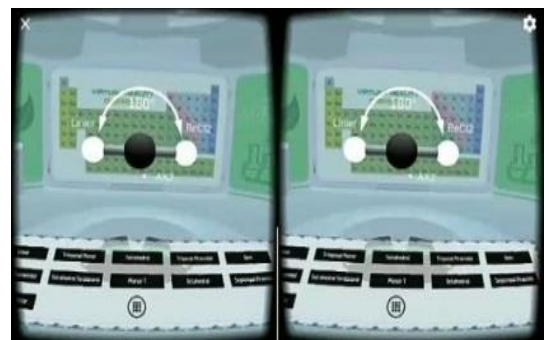

\section{Description:}

On the Video menu, there is 3D molecular geometry according to VSEPR Theory, and Hybridization Theory

10.

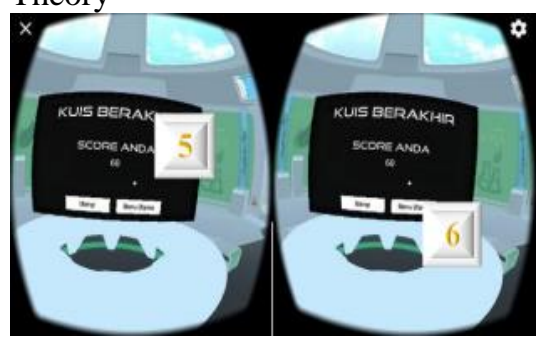

\section{Description:}

In the final menu of the Problem, there are the results of the evaluation of the problem.

The study was conducted by one lecturer of media and material experts, namely research supervisors. Conducted in the initial draft of VR-based learning videos that serve to get advice and input from media and material experts. From the results of the media study there needs to be a guidebook to facilitate the use of media and it is recommended that users have a VR BOX tool, in the $3 \mathrm{D}$ video menu should be rotated molecules, audio on learning videos replaced with learning delivery instruments, there is a steering sound on each scene making it easier for users, and there is a requirement to enter each menu to be controlled precepts of each learner. 
At the revision stage, improvement is carried out according to the advice and input of experts (media experts and media experts) to produce media that meets the criteria of feasibility as a learning medium. Here's Table 2. contains the results of revisions following the advice and input of experts. Then, from the results of the study obtained draft revision results such as advice that has been given by the supervisor, so that the media is ready to be validated to two validators, namely two chemistry teachers. The results of the study can be seen in table 4 .

\section{Table 4. Media Draft View After Revision}

\begin{tabular}{cll}
\hline No & \multicolumn{1}{c}{ Before Revision } & \multicolumn{1}{c}{ After Revision } \\
\hline 1. & $\begin{array}{l}\text { Audio media using forest atmosphere } \\
\text { sound instruments in the morning should } \\
\text { be changed the morning spirit instrument. }\end{array}$ & $\begin{array}{l}\text { At an beginning of the scene, there } \\
\text { accompanied by a learning spirit } \\
\text { instrument }\end{array}$ \\
& $-\begin{array}{l}\text { On each menu, there is a media } \\
\text { usage guide voice }\end{array}$
\end{tabular}

2.

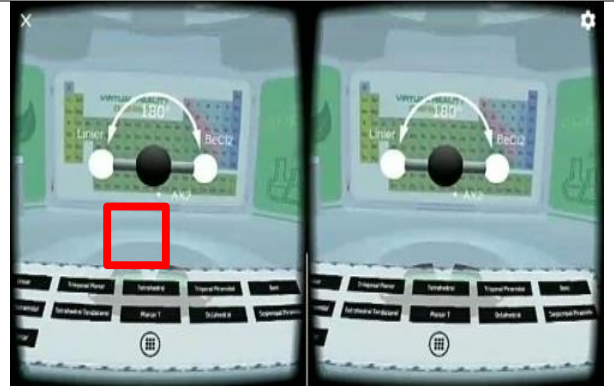

Criticisms and suggestions:

3D Form Molecules should be rotated so that like its looks it's a 3D model.

3.

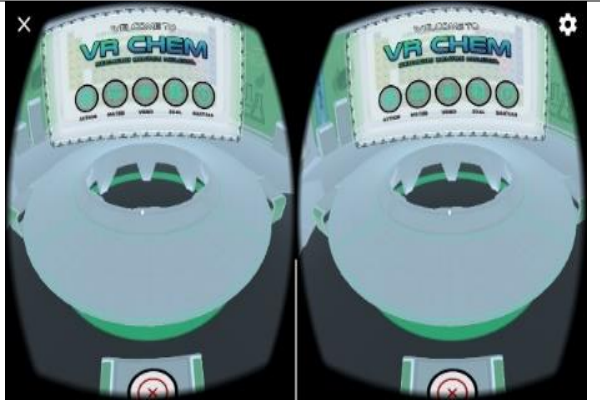

Criticisms and suggestions:

There should be a requirement to enter each menu to be controlled precepts of each student

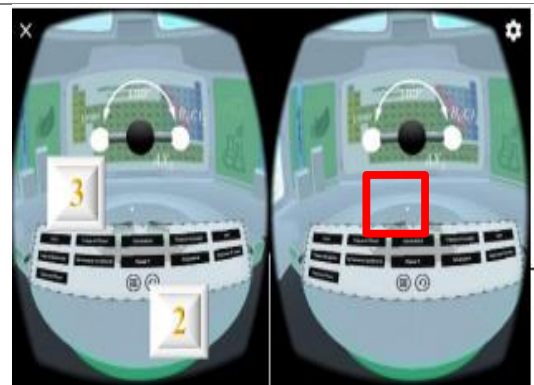

There is a rotation button on the video menu such as study suggestions

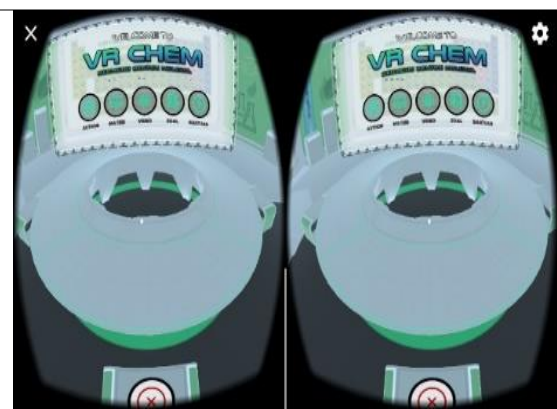

There is a condition that students can not access the material menu if they do not open the author menu first. 
4. Criticisms and suggestions:

There should be a guidebook to make it easier to curate media because VR technology is still rarely used in Indonesia

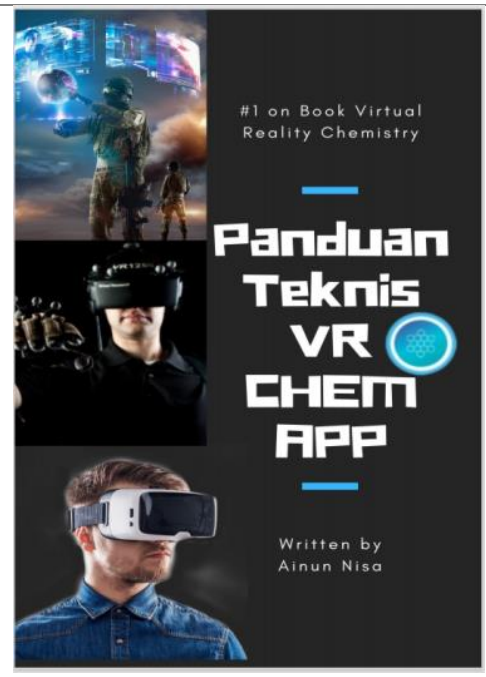

At the media validation stage, after the improvement process in VR-based learning video on molecular form geometry sub-material. Validation is done based on two aspects, namely the validity of the content and the validity of the construction. Where validation was done by 1 media expert lecturer and two chemistry teachers. The validation stage is useful to ensure that the media developed, in this case, virtual reality-based learning media on the geometry submaterial of molecular shapes is correct following the prevailing rules of science.

\section{Assessment and Analysis Stage}

The criteria assessed at the validation stage are two kinds, namely: the validity of the contents and the validity of the construction. The instrument used at this stage is a validation sheet that contains questions of aspects assessed and their assessment criteria. Validation sheet assessment is given with a Likert scale that is with the given value range is $1-5$, where the value of 1 refers to bad criteria, the value of 2 refers to less good, the value of 3 is enough, the value of 4 means good, and the value of 5 has a very good value meaning. In addition to containing media values, on the validation sheet is also there is column commiserate or suggestions. Comments or suggestions are aimed at the resulting media to have good quality.

The results of media validation that have been developed are described in detail as follows. It can be seen based on the criteria of content validity, Virtual realitybased learning videos developed have excellent assessment categories. This can be seen based on figure 6 . Based on the data in the validation diagram reviewed from the standard aspects of content and systematics of the content in figure 6, obtained an overall percentage of $91.9 \%$. If interpreted in table 2, about the interpretation of validation score, then the media developed into the category is very feasible. 


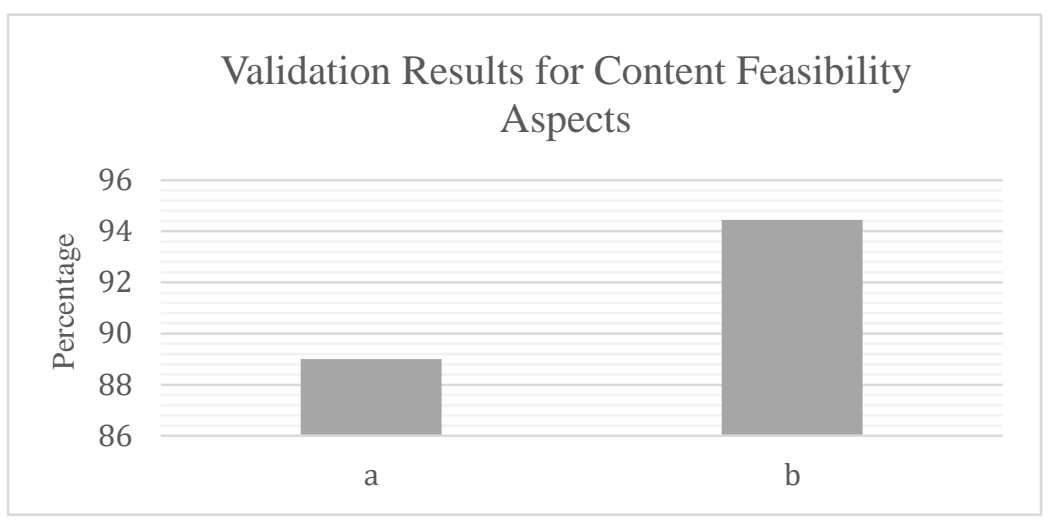

Figure 6. Content Validation Result Diagram

Description:

a. Content Standards

b. Systematic Content

Aspects of content validation according to the National Standards Board of Education (BSNP), broadly contains about the feasibility of media developed in terms of material and truth of the concept presented. One of the things presented. One of the things to note in this aspect is the association of basic competencies and learning indicators with the material presented.

A learning medium must have a clear focus on learning objectives. Learning objectives include skills that students are expected to master after the learning process is complete. In addition to being able to accommodate the learning indicators to be achieved, the material presented must also contain accurate data, to increase student insights and not cause misconceptions (Arsyad, 2015).

In-depth and thorough chemistry (Chittleborough, Treagust, \& Mocerino, 2002; Treagust, Chittleborough, \& Mamiala, 2003). The three levels of achievement in question are macroscopic, submicroscopic, and symbolic (Mansouri, 2007). The macroscopic representation can be interpreted that the chemical representation obtained through observation of phenomena that can be seen (seen) and felt by the senses or can be an experience obtained daily learner. In sub-material geometry, the shape of molecules represents chemistry in microscopic form, so it is necessary to learn media that can describe or visualize in real form.

Virtual Reality or which in Bahasa Indonesia is called virtual reality is a technology simulated by a computer or smartphone that can make users interact in an environment in real or in terms computer-simulated environment, meaning that the computer simulates the virtual environment and is projected on Virtual Reality media that makes it as if the user entered the world or the environment (Abdillah, 2018). With this medium sub material geometry of molecular shapes can be projected in real-time. Figure 7 is the validation result of this media. Based on figure 7 , the average percentage of overall validation results in the construction validation aspect is $89 \%$. 


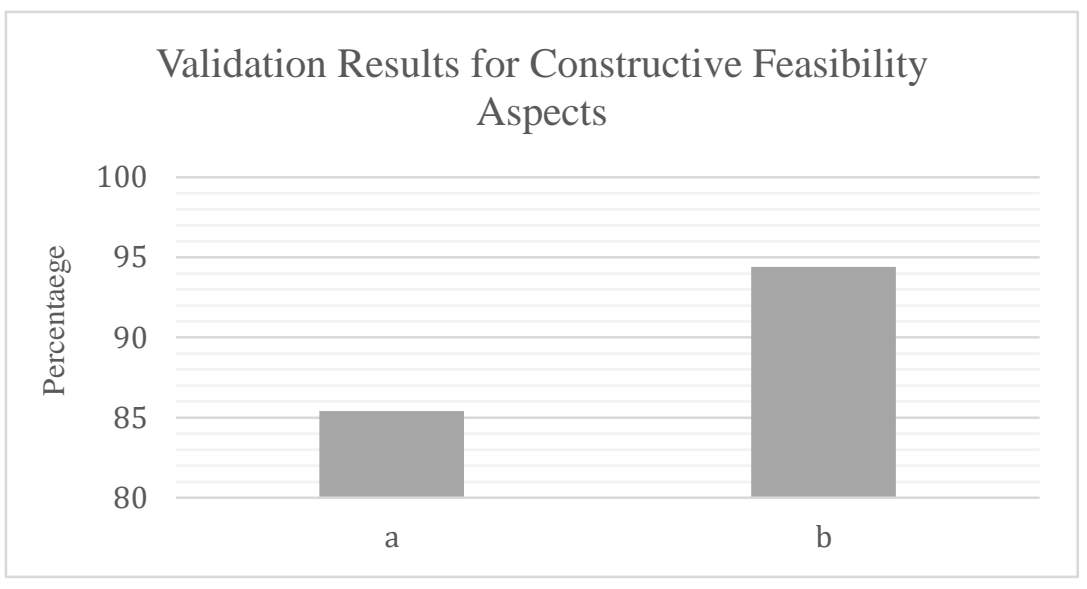

Figure 7. Results of Validation aspects of construction feasibility

Description:

a. Technical Software

b. Visual Communication

Concerning the interpretation of the validation score, the feasibility of virtual reality-based learning videos in terms of constructs is categorized as very feasible. Because the value obtained is in the range of $81-100 \%$. Virtual Reality-based learning video is a visual-based media that serves as a tool in the teaching and learning process and is expected to affect the learning environment for the better. The use of learning media in the teaching and learning process can develop new desires and interests, increase motivation in learning activities, and even be able to bring psychological influence to students. The same opinion was also expressed by Levie \& Lentz (2012), that learning media, especially visual media, can attract the interest and attention of learners to concentrate on the material discussed. This interest provides a great possibility in achieving learning goals (Arsyad, 2015).

\section{Conclusion}

Based on the description of the results and discussion above it can be concluded that the Virtual Reality-Based Molecular Shape Geometry Tutorial Video (VR CHEM) developed is very valid to use. This is reviewed from the validation results that get the category "Very Valid" on each criterion assessed. The details of the results obtained are content validation of $91.9 \%$ with the category "Very Valid" and validation of $89 \%$ presentation with the category "Very Valid".

\section{Acknowledgement}

I am grateful to all the components involved in this research. Grade 11 students who volunteered to participate in online learning and make research successful. As well as to families who always support the implementation of this research. 


\section{References}

Abdillah, F., Riyana, C., \& Alinawati, M. (2018). Pengaruh Penggunaan Media Virtual Reality Terhadap Kemampuan Analisis Siswa Pada Pembelajaran Ilmu Pengetahuan Alam Kelas VIII Sekolah Menengah Pertama. Educational Technologia, 2(1), 35-44.

Ahvan, Y. R., \& Pour, H. Z. (2016). The Correlation of Multiple Intelligences for the Achievements of Secondary Students. Educational Research and Reviews, 11(4), 141-145.

Aji, R. H. S. (2020). Dampak Covid-19 pada Pendidikan di Indonesia: Sekolah, Keterampilan, dan Proses Pembelajaran. SALAM: Jurnal Sosial dan Budaya Syar-i, 7(5), 395-402.

American Library Association. (2017). Trends. [Online]:(http://www.ala.org/tools/future/trends).

Arsyad, Azhar. (2015). Media Pembelajaran. Jakarta: PT Raja Grafindo Persada.

Bento de Sa, F., Carvalho de Paiva, R., Souki, G., \& Moura, L. (2017). Attributes Considered by Coffee Consumers During Their Buying Decision Process: A Study Using Factorial Analysis. Brasil. Universidade Federal de Lavras

Chittleborough, G. D., Treagust, D. F., \& Mocerino, M. (2002). Constraints to the development of first year university chemistry students' mental models of chemical phenomena. Focusing on the Student. 43-50.

Critten, V., Campbell, E., Farran, E., \& Messer, D. (2018). Visual Perception, Visual-Spatial Cognition And Mathematics: Associations And Predictions In Children With Cerebral Palsy. Research in developmental disabilities, 80, 180-191.

Firman. (2020). Dampak Covid-19 terhadap Pembelajaran di perguruan tinggi. BIOMA, 2(1), pp.14-2.

Gerschütz, B., Fechter, M., Schleich, B., \& Wartzack, S. (2019). A Review of Requirements and Approaches for Realistic Visual Perception in Virtual Reality. In Proceedings of the Design Society: International Conference on Engineering Design (Vol. 1, No. 1, pp. 1893-1902). Cambridge University Press.

Sukmawati, Wati. (2019). Analisis Level Makroskopis, Mikroskopis dan Simbolik Mahasiswa dalam Memahami Elektrokimia. Jurnal Inovasi Pendidikan IPA, 5 (2), 2019, 195-204.

Ibrahim, M. (2001). Model Pengembangan Perangkat Pembelajaran Menurut Jerold E. Kemp \& Thiagarajan. Surabaya: PSMS-PPS UNESA.

Levie, W. H. and Lentz, R. (2012). Effects of text illustrations: a review of research. Educational Communication and Technology Journal, 30, 195232.

Meyer, O. A., Omdahl, M. K., \& Makransky, G. (2019). Investigating The Effect Of Pre-Training When Learning Through Immersive Virtual Reality And Video: A Media And Methods Experiment. Computers \& Education, 140, 103603.

Mansouri, F. (2007). Cultural diversity as an educational advantage. Ethos, 15(3), 15-18. 
Pemerintah Indonesia. (2019). Undang-Undang Republik Indonesia Nomor 11 Tahun 2019 tentang Ilmu Pengetahuan dan Teknologi. Jakarta : Sekretariat Negara.

Permendikbud. (2018). Undang-Undang Republik Indonesia Nomor 37 Tahun 2018 tentang Perubahan Atas Peraturan Menteri Pendidikan Dan Kebudayaan Nomor 24 Tahun 2016 Tentang Kompetensi Inti Dan Kompetensi Dasar Pelajaran Pada Kurikulum 2013 Pada Pendidikan Dasar Dan Pendidikan Menengah. Jakarta: Sekretariat Negara.

Riduwan. (2007). Skala Pengukuran Variabel-variabel Penelitian. Bandung: Afabeth.

How to cite this article:

Nisa, A., Rifki, I. Y., Alya, A., \& Dwiningsih, K. (2021). The Validity of Molecular Geometry Based Virtual Reality to Improve Student Visual-Spatial Intelligence in New Normal Era. Journal of Educational Sciences, 5(3), 393408. 